\title{
Optimization of Blending Apple (Malus $\times$ domestica) Bars using Response Surface Methodology
}

\author{
Manpreet Kaur ${ }^{1}$, Naveet Kaushal ${ }^{3}$, Ajay Singh ${ }^{2}$ and Namneet Kaur ${ }^{2}$ \\ ${ }^{1}$ Department of Agriculture, ${ }^{2}$ Department of Food Technology, Mata Gujri College, \\ ${ }^{3}$ Department of Agriculture, Fatehgarh Sahib, India \\ *Corresponding author
}

\section{A B S T R A C T}

\section{Keywords \\ Optimization, Apple, \\ Response surface \\ methodology, Invert \\ syrup, Pectin, Citric \\ acid \\ Article Info \\ Accepted: \\ 15 June 2018 \\ Available Online: \\ 10 July 2018}

Firm ripe apple fruits mature and healthy red delicious apple variety was bought from the local market used for the study. Apple contains higher antioxidant compounds. It has the potential to be used as a healthy food. For the optimization of apple bar by response surface methodology, the experiments were conducted according to Central Composite Rotatable Design (CCRD) with three variables at five levels. The low and high levels of the variables were 7 and $10 \%$ invert syrup, 1000 and $1600 \mathrm{~W}$ temperature, 0.3 and $0.6 \%$ pectin, respectively. Out of twenty treatments, the best treatment with desirability one having invert syrup (7\%), pectin(6\%), temperature(1600W).

\section{Introduction}

Apple (Malus $\times$ domestica) is the fourth most important fruit crop after citrus, grapes and banana and one of the commercially most important horticultural crops grown in temperate parts of the world (Ferree and Warrington,2003). Apple belongs to the Rosaceae family which includes many wellknown genera with economically important fruits, particularly edible, temperate-zone fruits and berries such as apple, pear, almond, apricot, cherries, peach, plum, strawberries and raspberries. It is fourth important cash crop in the world (Janick et al., 2013). China being the first for apple production annually (Javed, 2013; Afandi, 2012; Khair et al., 2006). In India apple cultivated area is 277000 ha whereas its production and productivity is $2242000 \mathrm{mt}$ and 8 $\mathrm{mt} /$ ha(nhb.gov.in, 2016-2017). Major apple producing states in India are Jammu\&Kashmir, Himachal Pradesh, Arunachal Pradesh, Uttranchal. Himachal Pradesh is also known as "apple bowl" of India. Apple fruit also known as king of temperate fruits. Apples contain over 84\% water and a rich source of antioxidant, pytonutrients, flavonoids and polyphenolics. Flavonoids in apples are quercetin and 
procyanidin $\mathrm{B}_{2}$. Additionally, they are also good in tartaric acid that gives tart flavour to them. Apple fruit contains good quantities of vitamin-C, betacarotene, minerals $(\mathrm{K}, \mathrm{Mg}, \mathrm{Ca}$, and $\mathrm{Na}$ ) trace elements $(\mathrm{Zn}, \mathrm{Mn}, \mathrm{Cu}, \mathrm{Fe}, \mathrm{B}, \mathrm{F}$, $\mathrm{Se}, \mathrm{Mo})$ and have high fiber content.

Fruit leathers or bars are dehydrated fruit based products in which the destruction of original fruit structure by pureeing and restructuring in dehydrated sugar-acid- pectin gels provide attractive, coloured products, on which research is enhanced now-a- days. Fruit leathers also allow left over ripe fruits to be preserved (Natalia et al., 2011). Fruit leathers are dried sheets of fruit pulp that have a soft, rubbery texture and sweet taste. They are produced by dehydrating of fruit puree into a leathery sheet (Raab and Oehler, 1999). Apple bar can also be prepared by using apple juice concentrate (AJC), invert syrup, pectin and citric acid. In this way, the AJC could be used to give a natural sweet taste to the fruit leather. Invert syrup is sweeter than ordinary sugar and provides texture to fruit leather. Moreover, incorporation of pectin would improve the physicochemical and sensory properties of the product. Citric acid act as preservative and also add acidic taste to fruit leather (Huang, et al., 2005). The aim of this work was to standardize the method of preparation of apple bar with different concentration of invert syrup, pectin, temperature and constant concentration of citric acid, using response surface methodology with the purpose of achieving maximum possible colour and appearance, mouthfeel and texture, reducing sugar, polyphenols and overall acceptability.

\section{Materials and Methods}

\section{Experimental design}

For the optimization of apple bar by response surface methodology, the experiments were conducted according to Central Composite Rotatable Design (CCRD) with three variables at five levels. The independent variables were invert syrup, power, and pectin. The low and high levels of the variables were 7 and $10 \%$ invert syrup, 1000 and $1600 \mathrm{~W}$ power, 0.3 and $0.6 \%$ pectin, respectively (Ade- Omowaye et al., 2002). The relationship between levels of different coded and uncoded form of independent variables is given in Table 1 . The experiments plan in coded and uncoded form of process variables along with results is as given in Table 2. The experiments were conducted randomly to minimize the effects of unexplained variability in the observed responses because of external factors.

\section{Preparation of sample}

Good quality fresh, mature and healthy Red Delicious apple variety was bought from the local market. The uniform sized healthy, disease free fruits with full maturation and firm texture were selected and washed with water in order to remove dust, dirt and any other foreign material. The fruit was peeled, trimmed, cut and blanched in boiling water at $96^{\circ} \mathrm{C}$ temperature for $3 \mathrm{~min}$. and then immediately the slices were dipped into cold water for 4 min. to prevent oxidation. The TSS was measured with Erma hand refractrometer. The main ingredients used to prepare apple leather/bar were apple juice, invert syrup, pectin and citric acid with different formulations as per predicted/designed by response surface methodology.

\section{Fruit bar preparation}

Flow chart for preparation of apple fruit bar

Selection of apple fruits

Washing with clean water 
Blanching of fruits

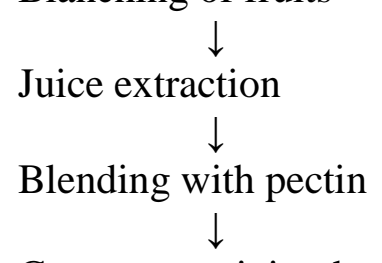

Concentrate juice by continuous boiling upto $1 / 4^{\text {th }}$ of volume

$\downarrow$
$\downarrow$
$\downarrow$

Boiling and juding end point (drop test)

Addition of citric acid

Spreading on trays (0.5-1 cm thick layer)

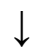

Cutting in to pieces and packing in butter paper

Storage in ziplock bags

\section{Statistical analysis and optimization}

Design expert software was used to estimate the response of the dependent variables. The response function (y) was related to coded variable $\left(\mathrm{x}_{\mathrm{i}}, \mathrm{i}=1,2,3\right)$ by second polynomial equation as given below:

$\mathrm{Y}=\mathrm{b}_{0}+\mathrm{b}_{1} \mathrm{x}_{1}+\mathrm{b}_{2} \mathrm{x}_{2}+\mathrm{b}_{3} \mathrm{x}_{3}+\mathrm{b}_{12} \mathrm{x}_{1} \mathrm{x}_{2}+\mathrm{b}_{13} \mathrm{x}_{1}$ $\mathrm{x}_{3}+\mathrm{b}_{23} \mathrm{x}_{2} \mathrm{x}_{3}+\mathrm{b}_{11} \mathrm{x}_{1}{ }^{2}+\mathrm{b}_{22} \mathrm{x}_{2}{ }^{2}+\mathrm{b}_{33} \mathrm{x}_{3}{ }^{2}+\varepsilon-----(1)$

The variance for each factor assumed was partitioned into linear, quadratic and interactive components. The coefficient of the polynomial were represented by $b_{0}$ (constant), $b_{1} b_{2} b_{3}$ (linear effect), $b_{12} b_{13} b_{23}$ (interaction terms), $b_{11}, b_{22}, b_{33}$ (quadratic effect) and $\varepsilon$ (random error). The significance of all the term in the polynomial function was assumed statistically using $\mathrm{F}$ value at probability $(\mathrm{P})$ of 0.05 .

The response surface and contour plots were generated for different interaction of any two independent variables, while holding the value of third variable as constant (at the central value). Such three dimensional surfaces could give accurate geometrical representation and provide useful information about the behavior of the system within the experimental design. The optimization of apple bar process was aimed at finding the levels of independent variables viz. invert syrup, power, and pectin, which would give maximum possible colour and apperance, mouthfeel and texture, overall acceptability. It will also help to make the product shelf stable at ambient conditions Response surface methodology was applied to the experimental data using commercial statistical package, Design-Export version 8.01 (Trail version; Statease Inc., Minneapolis, MN,USA). The same software was used for the generation of response surface plots, superimposition of contour plots, and optimization of process variables.

\section{Mathematical calculations}

\section{Reducing sugar}

The results were calculated using formula stated below and were expressed as percentage of reducing sugars.

Reducing $\operatorname{sugars}(\%)=$

Factor $\mathrm{x}$ dilution $\times 100$

Weight of fresh sample $\mathrm{x}$ titre reading

\section{Polyphenols}

The DPPH radical scavenging activity of drying apples was determined according to the method of Yen etal. [1996]. The DPPH solution $(1 \mathrm{~mL})$ was added to $1 \mathrm{~mL}$ of centrifuged methanol extracts with $3 \mathrm{~mL}$ of ethanol. The mixture was shaken vigorously and allowed to stand at room temperature in the dark for $10 \mathrm{~min}$. The decrease in absorbance 
was measured at $517 \mathrm{~nm}$ using a Shimadzu UV-2401 PC spectrophotometer. Ethanol was used to zero spectrophotometer. All determinations were performed in triplicate.
The results were corrected for dilution and expressed in $\mu \mathrm{mol}$ Trolox per $100 \mathrm{~g}$ dry weight (dw).

$\mathrm{mg} / 100 \mathrm{gm}$ sample total polyphenols $=$

Concentration of polyphenols from graph

Aliquot taken for estimation $\times 5 \times 100 /$ Weight of sample $\times 1 / 100$

\section{Sensory evaluation of apple bar}

Organoleptic quality of apple bar determined with the help of a 10-member consumer panel, using a 9-point hedonic scale, following standard procedure. The aspects considered for apple bar were colour, appearance, taste, favour, and overall acceptability. The average scores of all the 10 panelists were computed for different characteristics.

\section{Results and Discussion}

Fitted model and surface plots for colour and appearance

The results of second-order response surface model in the form of analysis of variance (ANOVA) are given in Tables 3, 4 and 5.ANOVA results in table showed that the linear terms of pectin had significant effect at $\mathrm{P}<0.0001$ where other process variables had no significant value and also effect of pectin on response variables show in Fig. 1(a).A product's value is related in part to its good appearance. Analysis of variance (ANOVA) was used to test the significance of the product formulation on the color parameters. The fit of the model was expressed by R-squared, which was found to be 0.9150 indicating that $91.50 \%$ of the variability of the response could be explained by the model.
The following graphs (Fig.1) showed interactions between different process variables on colour and appearance. Fig. 1(a) shows that no significant effect of invert syrup and power on colour and appearance of product. Fig. 1(b) shows that interaction effect of power and pectin on colour and appearance. Pectin shows significant effect on colour and appearance of product.

\section{Fitted model and surface plots for mouthfeel and texture}

This study analysed the effect of the invert syrup, pectin and power on the mouthfeel and texture of the apple fruit bar. The linear and quadratic model found to be significant as depicted in (Table 4). In this case B, C, BC are significant model terms. Pectin and Power has shown a significant effect on response variable. The addition of invert syrup and pectin enhanced the response of mouthfeel and on the texture attributes in Fig. 4 depicted a significant effect of pectin and invert syrup. The linear, quadratic and cubic model found to be significant but quadratic model was used for ANOVA (Table 4). The values of prob $>F$ less than 0.0500 indicate model terms are significant. The fit of the model was expressed by R-squared, which was found to be 0.7527 indicating that $75.27 \%$ of the variability of the response could be explained by model. 
Table.1 Coded and assigned concentrations of variables of different levels of the central composite design

\begin{tabular}{|l|c|c|c|}
\hline Independent variables & \multicolumn{3}{|c|}{ Levels } \\
\cline { 2 - 4 } & \multicolumn{2}{|c|}{$\mathbf{- 1}$} & $\mathbf{0}$ \\
\hline Invert syrup (\%) & $\mathbf{7}$ & $\mathbf{8 . 5}$ & $\mathbf{1 0}$ \\
\hline Power (watt) & $\mathbf{1 0 0}$ & $\mathbf{1 3 0 0}$ & $\mathbf{1 6 0 0}$ \\
\hline Pectin (\%) & $\mathbf{0 . 3}$ & $\mathbf{0 . 4 5}$ & $\mathbf{0 . 6}$ \\
\hline
\end{tabular}

Table.2 Central Composite Rotatable Design with experimental values of response variables

\begin{tabular}{|c|c|c|c|c|c|c|c|c|c|}
\hline $\overrightarrow{\vec{n}}$ & $\Xi$ & 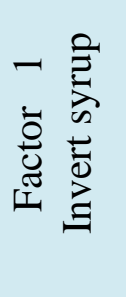 & 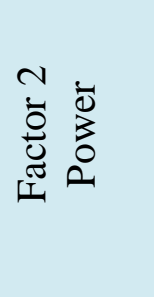 & 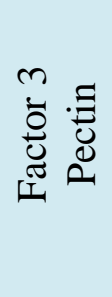 & 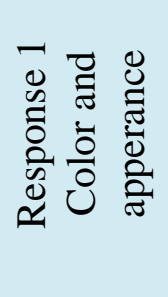 & 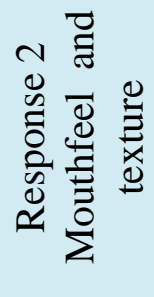 & 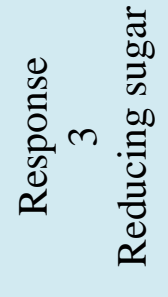 & 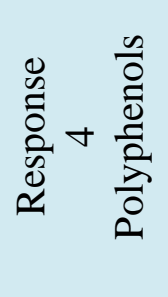 & 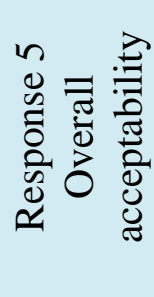 \\
\hline 7 & 1 & 7.00 & 1600.00 & 0.60 & 7.0 & 7.5 & 15.5 & 25 & 8.0 \\
\hline 5 & 2 & 7.00 & 1000.00 & 0.60 & 6.0 & 6.0 & 15.3 & 30 & 8.0 \\
\hline 3 & 3 & 7.00 & 1600.00 & 0.30 & 6.5 & 6.5 & 14.5 & 23 & 7.0 \\
\hline 2 & 4 & 10.00 & 1000.00 & 0.30 & 6.5 & 6.0 & 18.5 & 28 & 7.0 \\
\hline 4 & 5 & 10.00 & 1600.00 & 0.30 & 5.5 & 6.0 & 18.0 & 27 & 7.0 \\
\hline 15 & 6 & 8.50 & 1300.00 & 0.45 & 6.5 & 6.0 & 15.0 & 28 & 6.0 \\
\hline 10 & 7 & 11.02 & 1300.00 & 0.45 & 7.0 & 6.5 & 17.0 & 26 & 6.0 \\
\hline 13 & 8 & 8.50 & 1300.00 & 0.20 & 5.5 & 5.5 & 16.0 & 26 & 7.0 \\
\hline 12 & 9 & 8.50 & 1804.54 & 0.45 & 7.0 & 7.0 & 16.5 & 20 & 6.0 \\
\hline 19 & 10 & 8.50 & 1300.00 & 0.45 & 6.5 & 6.0 & 16.5 & 27 & 7.0 \\
\hline 9 & 11 & 5.98 & 1300.00 & 0.45 & 7.0 & 5.5 & 14.0 & 25 & 6.0 \\
\hline 16 & 12 & 8.50 & 1300.00 & 0.45 & 6.5 & 6.0 & 16.5 & 26 & 6.0 \\
\hline 11 & 13 & 8.50 & 795.46 & 0.45 & 7.0 & 5.5 & 16.5 & 29 & 6.0 \\
\hline 20 & 14 & 8.50 & 1300.00 & 0.45 & 6.5 & 6.5 & 16.0 & 27 & 7.0 \\
\hline 1 & 15 & 7.00 & 1000.00 & 0.30 & 6.5 & 6.0 & 14.5 & 29 & 6.0 \\
\hline 6 & 16 & 10.00 & 1000.00 & 0.60 & 7.0 & 5.5 & 18.5 & 28 & 6.0 \\
\hline 18 & 17 & 8.50 & 1300.00 & 0.45 & 6.5 & 6.0 & 16.5 & 25 & 6.5 \\
\hline 14 & 18 & 8.50 & 1300.00 & 0.70 & 7.0 & 6.5 & 15.0 & 26 & 6.0 \\
\hline 17 & 19 & 8.50 & 1300.00 & 0.45 & 6.5 & 6.0 & 16.5 & 25 & 6.5 \\
\hline 8 & 20 & 10.00 & 1600.00 & 0.60 & 7.0 & 7.0 & 15.0 & 28 & 5.0 \\
\hline
\end{tabular}


Table.3 ANOVA for Response Surface Quadratic Model for colour and appearance

\begin{tabular}{|l|l|l|l|l|l|l|}
\hline Source & $\begin{array}{l}\text { Sum of } \\
\text { Squares }\end{array}$ & Df & $\begin{array}{l}\text { Mean } \\
\text { Squares }\end{array}$ & F value & p-value & Prob $>$ F \\
\hline Model & 3.79 & 9 & 0.42 & 11.96 & 0.0003 & Significant \\
\hline A(Invert Syrup) & 0.000 & 1 & 0.000 & 0.000 & 1.0000 & \\
\hline B(Power) & 0.000 & 1 & 0.000 & 0.000 & 1.0000 & \\
\hline C(Pectin) & 1.50 & 1 & 1.50 & 42.57 & $<0.0001$ & \\
\hline AB & 0.50 & 1 & 0.50 & 14.21 & 0.0037 & \\
\hline AC & 0.50 & 1 & 0.50 & 14.21 & 0.0037 & \\
\hline BC & 0.50 & 1 & 0.50 & 14.21 & 0.0037 & \\
\hline $\mathbf{A}^{\mathbf{2}}$ & 0.21 & 1 & 0.21 & 5.98 & 0.0345 & \\
\hline $\mathbf{B}^{2}$ & 0.21 & 1 & 0.21 & 5.98 & 0.0345 & \\
\hline $\mathbf{C}^{2}$ & 0.30 & 1 & 0.30 & 8.54 & 0.0153 & \\
\hline
\end{tabular}

$\mathrm{R}^{2}=0.9150$, Adj $\mathrm{R}^{2}=0.8384$, Pred $\mathrm{R}^{2}=0.3568$

Table.4 ANOVA for Response Surface Quadratic Model for Mouthfeel and texture

\begin{tabular}{|l|l|l|l|l|l|l|}
\hline Source & $\begin{array}{l}\text { Sum of } \\
\text { Squares }\end{array}$ & Df & $\begin{array}{l}\text { Mean } \\
\text { Squares }\end{array}$ & F value & p-value & Prob>F \\
\hline Model & 4.24 & 6 & 0.71 & 6.60 & 0.0022 & Significant \\
\hline A(Invert Syrup) & $\begin{array}{l}2.420 \mathrm{E}- \\
003\end{array}$ & 1 & $2.420 \mathrm{E}-003$ & 0.023 & 0.8829 & \\
\hline B(Power) & 2.66 & 1 & 2.66 & 24.77 & 0.0003 & \\
\hline C(Pectin) & 0.74 & 1 & 0.74 & 6.91 & 0.0208 & \\
\hline AB & 0.031 & 1 & 0.031 & 0.29 & 0.5984 & \\
\hline AC & 0.031 & 1 & 0.031 & 0.29 & 0.5984 & \\
\hline BC & 0.78 & 1 & 0.78 & 7.29 & 0.0182 & \\
\hline
\end{tabular}

$\mathrm{R}^{2}=0.7527$, Adj $\mathrm{R}^{2}=0.6386$, Pred $\mathrm{R}^{2}=0.0189$

Table.5 ANOVA for Response Surface 2FI Model for Reducing sugar

\begin{tabular}{|l|l|l|l|l|l|l|}
\hline Source & $\begin{array}{l}\text { Sum of } \\
\text { Squares }\end{array}$ & Df & $\begin{array}{l}\text { Mean } \\
\text { Squares }\end{array}$ & F value & p-value & Prob>F \\
\hline Model & 24.75 & 6 & 4.12 & 8.47 & 0.0007 & Significant \\
\hline A(Invert Syrup) & 17.02 & 1 & 17.02 & 34.96 & $<0.0001$ & \\
\hline B(Power) & 1.06 & 1 & 1.06 & 2.17 & 0.1644 & \\
\hline C(Pectin) & 0.61 & 1 & 0.61 & 1.25 & 0.2840 & \\
\hline AB & 2.20 & 1 & 2.20 & 4.53 & 0.0530 & \\
\hline AC & 2.88 & 1 & 2.28 & 5.92 & 0.0302 & \\
\hline BC & 0.98 & 1 & 0.98 & 2.01 & 0.1795 & \\
\hline
\end{tabular}

$\mathrm{R}^{2}=0.7964$, Adj $\mathrm{R}^{2}=0.7024$, Pred $\mathrm{R}^{2}=0.2868$ 
Table.6 ANOVA for Response Surface Linear Model for polyphenols

\begin{tabular}{|l|l|l|l|l|l|l|}
\hline Source & $\begin{array}{l}\text { Sum of } \\
\text { Squares }\end{array}$ & Df & $\begin{array}{l}\text { Mean } \\
\text { Squares }\end{array}$ & F value & p-value & Prob $>F$ \\
\hline Model & 57.45 & 3 & 19.15 & 7.41 & 0.0025 & Significant \\
\hline A(Invert Syrup) & 2.36 & 1 & 2.36 & 0.91 & 0.3531 & \\
\hline B(Power) & 53.92 & 1 & 53.92 & 20.87 & 0.0003 & \\
\hline C(Pectin) & 1.17 & 1 & 1.17 & 0.45 & 0.5103 & \\
\hline
\end{tabular}

$\mathrm{R}^{2}=0.5815$, Adj $\mathrm{R}^{2}=0.5031$, Pred $\mathrm{R}^{2}=0.2805$

Table.7 ANOVA for Response Surface 2FI Model for overall acceptability

\begin{tabular}{|l|l|l|l|l|l|l|}
\hline Source & $\begin{array}{l}\text { Sum of } \\
\text { Squares }\end{array}$ & Df & $\begin{array}{l}\text { Mean } \\
\text { Squares }\end{array}$ & F value & p-value & Prob>F \\
\hline Model & 6.88 & 6 & 1.15 & 4.12 & 0.0155 & Significant \\
\hline A(Invert Syrup) & 1.17 & 1 & 1.17 & 4.21 & 0.0610 & \\
\hline B(Power) & 0.000 & 1 & 0.000 & 0.000 & 1.0000 & \\
\hline C(Pectin) & 0.21 & 1 & 0.21 & 0.74 & 0.4042 & \\
\hline AB & 0.50 & 1 & 0.50 & 1.79 & 0.2033 & \\
\hline AC & 4.50 & 1 & 4.50 & 16.1 & 0.0015 & \\
\hline BC & 0.50 & 1 & 0.50 & 1.79 & 0.2033 & \\
\hline
\end{tabular}

$\mathrm{R}^{2}=0.6551$, Adj $\mathrm{R}^{2}=0.4959$, Pred $\mathrm{R}^{2}=0.1189$

Figure.1 Interaction effect of (a)invert syrup and power, (b) pectin and power on colour and appearance
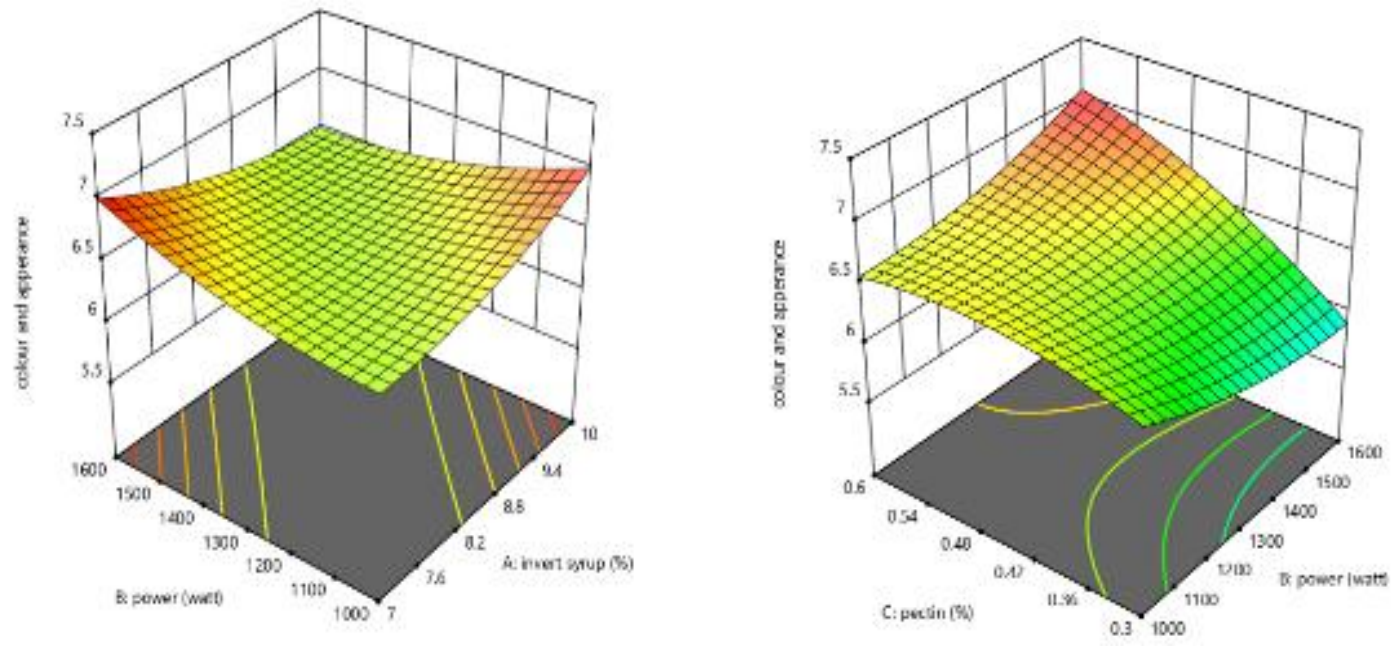
Figure.2 Interaction effect of (a)invert syrup and power, (b)power and pectin on mouthfeel and texture
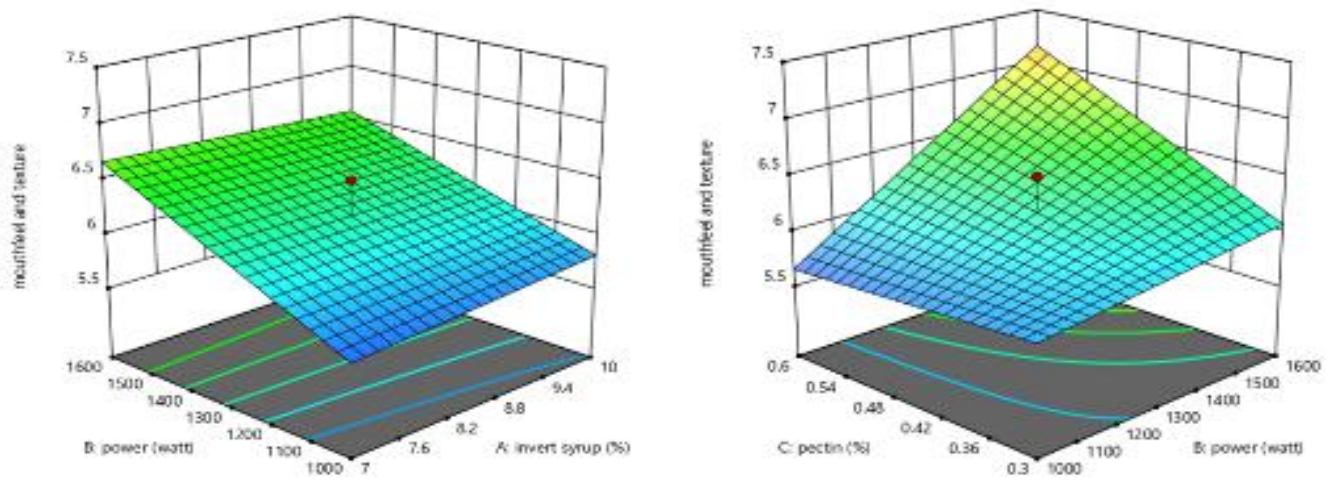

Figure.3 Interaction effect of (a) invert syrup and power, (b) power and pectin on reducing sugars
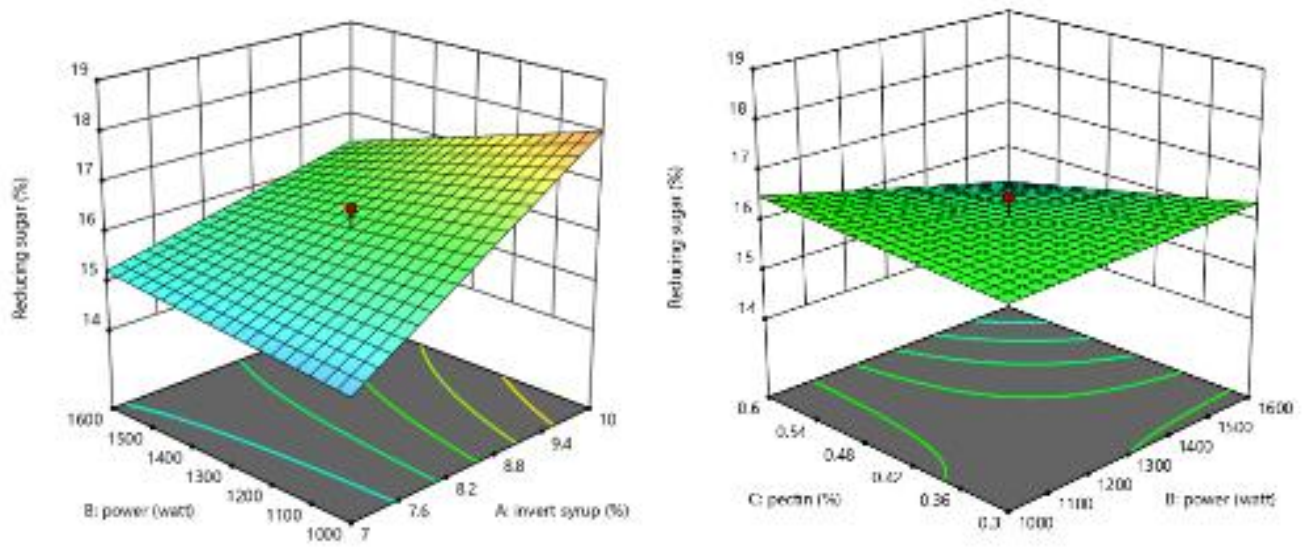

Figure.4 Interaction effect of invert syrup, power on polyphenols

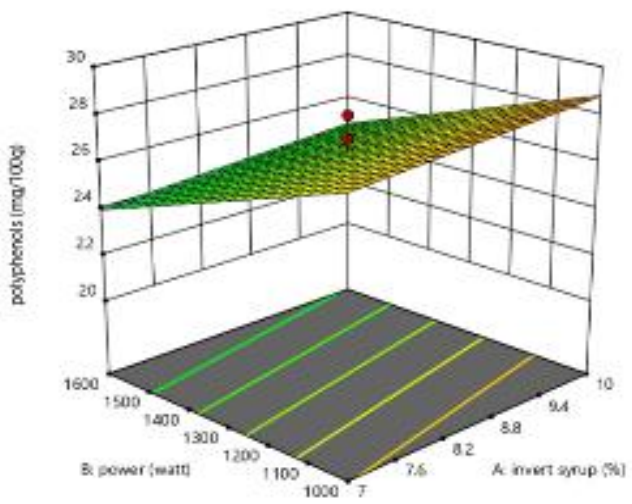


Figure.5 Interaction effect of (a) Invert syrup and Power, (b)Power and Pectin on overall acceptability

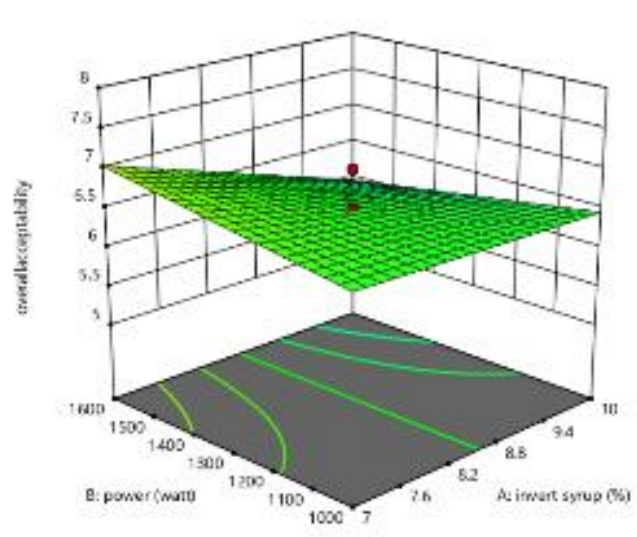

The following graphs (Fig.2) showed interactions between different process variables on mouthfeel and texture. Fig. 2(a) shows that significant effect of invert syrup and power on mouthfeel and texture. Fig. 2(b) shows that negative effect of power and pectin on mouthfeel and texture. Power shows significant effect on mouthfeel and texture of product.

\section{Fitted model and surface plots for reducing sugar}

It has been observed in this study that the addition variables factors had the significant effect on the reducing sugars of apple fruit bar. The quadratic model showed the significant value(Table 5). The invert syrup is a rich source of sugars and its addition had significant effect at $\mathrm{P}<0.0001$. The pectin and power isolate had a significant effect at $<0.05$. Fig. 3 showed a correlating effect of power and invert syrup. It is depicted that the power of $1000 \mathrm{~W}$ would be optimum for $10 \%$ invert syrup concentration with the pectin concentration of $0.30 \%$. The $\mathrm{F}$ value of 8.47 implies model is significant. The fit of model was expressed by the R-square, which was found to be 0.7964 indicating that $79.64 \%$ of the variability of the response could be explained by the model. The graph showed the significant effect of invert syrup on reducing sugar and it was also depicted that within increase in invert syrup a decreasing in reducing sugars was observed.

The following graphs (Fig.3) showed interactions between different process variables on reducing sugars. Fig. 3(a) shows that significant effect of invert syrup and power on reducing sugar. Fig. 3(b) shows that positive effect of power and pectin on reducing sugar. Invert syrup shows significant effect on reducing sugar of product.

Fitted model and surface plots for polyphenols

The addition of ingredients in fruit bar enhanced the polyphenols content of the food product and showed the significant values in ANOVA (Table 6). In this case, the model has shown a significant effect and the F-value of 7.41 implies the model significant. Fig.4 showed the interaction of variables A (invert syrup) and B (power) when the response (polyphenols) varied from the range 20-30 and it is depicted from the fig. 6 that a maximum of $28 \%$ polyphenols can be estimated at the 1000 $\mathrm{w}$ power and $10 \%$ invert syrup respectively. The fit of the model was expressed by the Rsquare, which was found to be 0.5815 indicating that $58.15 \%$ of the variability of the response could be explained by the model. 
The following graphs (Fig.4) showed interactions between different process variables on polyphenols. Fig. 4 shows that positive effect of invert syrup and power on polyphenols. Power shows significant effect on polyphenols of product.

\section{Fitted model and surface plots for overall acceptability}

The color, texture and flavour of the products with different formulations were analysed on the hedonic scale 0-9.The high amount of invert syrup and pectin lowered the textural quality of product as it increased the hardness and product lost its firmness. A quadratic model was found to be significant in (Table 7).A quadratic model was used for ANOVA analysis. The invert syrup and pectin isolates showed the significant values. The affect of invert syrup and pectin on overall acceptability shows in Fig.5. The effect of invert syrup on overall acceptability expressed by the R-square, which was found to be 0.6551 indicating that $65.51 \%$ of the variability of response could be explained by the model.The model expressed that overall acceptability increase within concentration of invert syrup.

The following graphs (Fig.5) showed interactions between different process variables on overall acceptability. Fig. 5(a) shows that significant effect of invert syrup and power on overall acceptability. Fig. 5(b) shows that negative effect of power and pectin on overall acceptability. Invert syrup and pectin shows significant effect on overall acceptability.

\section{References}

Ade-Omowaye, B.I.O., Rastogi, N. K., Angersbach, A. and Knorr, D., 2002. Osmotic dehydration behavior of red paprika (Capsicum annuum L.). Journal of Food Science, 67:1790-1796.

Alonso-Salces D, Barranco A, (2004). Polyphenolic Profiles of Basque Cider Apple Cultivars and Their Technological Properties. Journal of
Agricultural and Food Chemistry 52(10): 2938-2952.

Bandaru VVR, Somalanka SR, Mendu D R, Madicheria N R and Chityala A (2006) Optimization of fermentation conditions for the production of ethanol from sago starch by co- immobilized amyloglucosidase and cells of Zymomonas mobilis using response surface methodology. Enzyme Microbial Technol 38: 209-14

Budi, S, Ahmad Suaeman, David W. Giraud, and Judy A. Driskell. 2001. Carotenoid content of selected Indonesian fruits. Journal of Food Composition and Analysis. 14: 169-176.

BeveridgeT, Franz KY, Harrison JE, (1986). Clarified natural apple juice: production and storage stability of juice and concentrate. Journal of Food Science 51: 411-414.

Cherian, B and Cheriayan, S. 2003. Acceptability study on blended papaya leather. Journal Food Science and Technology. 40(3): 293-295.

Downing D, (1989). Processed apple products. New York Van Nostrad Reinhold

Eberhardt MV, Lee CY, Liu RH, (2000). Antioxidant activity of fresh apples. Nature 405(6789): 903- 904.

Gowda DIN, Dan A and Ramanjaneya KH. 1995. Studies on mango fruit bar preparation. Indian Food Packer. 49 (2): 17-24.

Garcia-Alonso M, Pascual-Teresa S, SantosBuelga $\mathrm{C}$ and Rivas-Gonzalo JC. 2004.Gujral,

H. S., \& Khanna, G. (2002). Effect of skim milk powder, soy protein concentrate and sucrose on the dehydration behaviour, texture, color and acceptability of mango leather. Journal of Food Engineering, 55(4), 343-348.

Harsimrat, K. and Dhawan, S. S. 1998. Preparation of guava fruit bar. Poster abstrct. IFCON O-04: 533.

Larmand, E. 1977.Lab. Method of sensory evaluation of food. Pub. Canada, Deptt. Agric. Ottawa. Seymour G. B. \& Knox 
J. P. 2002.

Lee KW, Kim YJ, Lee HJ, Lee CY, (2003). Major Phenolics in Apple and Their Contribution to the Total Antioxidant Capacity. Journal of Agricultural and Food Chemistry 51(22): 6516-6520.

Lee, W.C., Yusof, S., Hamid N.S.A. and Baharin, B.S., 2006. Optimizing conditions for enzymatic, Clarification of banana juice using response surface methodology (RSM). Journal of Food Engineering, 73: 55-63.

Lane, J.H. and Eynon, L. 1923. Determination of reducing sugars by means of Fehling's solution with methylene blue as internal indicator. J. Soc. Chem. Ind. Trans. 42:32-36.

Mahony MO. 1985. Sensory evaluation of food: statistical methods and procedures. Marcel Dekker. New York. 168-169.

Moyls, A. L. 1981. Drying of apple purees. Journal of Food Science, 46(3): 939942.

Marcus-Karel DBL, (2003). Physical Principles of Food Preservation. New York CRC Press

Mudahar, G.S., Toledo, R.T., Floros, J.D. and Jen, J. J., 1989. Optimization of carrot dehydration process using response surface methodology. Journal of Food Science, 54:714- 719.

Namiki, M. (1988). Chemistry of Maillard reactions: recent studies on the browning reaction mechanism and the development of antioxidants and mutagens. Advances in Food Research. 32:115-143.

National Horticulture Board DataBase. 201213. http://www.nhb.gov.in.

Oszmianski, J., Wolniak, M., Wojdylo, A., \& Wawer, I. (2008). Influence of apple purée preparation and storage on polyphenol contents and antioxidant activity.Food Chemistry, 107(4), 14731484.

Oszmianski J, Wolniak M, Wojdyło A, Wawer I, (2007). Comparative study of polyphenolic content and antiradical activity of cloudy and clear apple juices. Journal of the Science of Food and Agriculture 87(4): 573-579.

Pectins and their manipulation. Blackwell publishing, Boca Raton, Florida, Eds.; Blackwell Publishing Professional: Ames, IA, USA, 2008; pp. 237-272

Padmashree, A, Gopal kumar Sharma, Srihari, K.A, and Amarinder Singh Bawa. 2012. Development of shelf stable protein rich composite cereal bar. Food Sci. Tecnol. 49(3): 335-341.

Sanoner P, Guyot S, Marnet N, (1999). Yağcı S, Gögüsş F, (2008). Response surface methodology for evaluation of physical and functional properties of extruded snack foods developed from food-byproducts. Journal of Food Engineering 86(1): 122-132. Journal of Agricultural and Food Chemistry 47(12): 4847-48

Visser J. and Voragen A. 1995. Pectins and Pectinases. Elsevier Science B.V., Amsterdan, Holand.

Wanasundara and Shahidi, F., 1996. Optimization of hexa metaphosphateAssisted Extraction of Flaxseed Proteins Using Response Surface Methodology. Journal of Food Science, 61 (3):604 $\square 607$.

Wu, J., Gao, H., Zhao, L., Liao, X., Chen, F., \&Wang, Z. (2007). Chemical compostion characterization of some apple cultivars. Food Chemistry, 103(1), 88-93.

\section{How to cite this article:}

Manpreet Kaur, Naveet Kaushal, Ajay Singh and Namneet Kaur. 2018. Optimization of Blending Apple (Malus $\times$ domestica) Bars using Response Surface Methodology. Int.J.Curr.Microbiol.App.Sci. 7(07): 1910-1920. doi: https://doi.org/10.20546/ijcmas.2018.707.226 